\title{
ATMOSPHERIC CARBON DIOXIDE REDUCTION BY SACRAMENTO'S URBAN FOREST
}

\author{
by E. Gregory McPherson
}

\begin{abstract}
Sacramento County's 6 million trees store 8 million tons of $\mathrm{CO}_{2}(31 \mathrm{t} / \mathrm{ha})$, and annually sequester 238,000 $\mathrm{t}(0.92 \mathrm{t} / \mathrm{ha})$. Air-conditioning (157 GWh) and space-heating (145 TJ) savings from the urban forest further reduce emissions by $75,600 \mathrm{t}$ of $\mathrm{CO}_{2}$ annually $(0.29 \mathrm{t} / \mathrm{ha})$. These avoided emissions are only $32 \%$ of the amount sequestered, due to a clean, hydroelectric energy supply. Annual $\mathrm{CO}_{2}$ release associated with tree maintenance is estimated at $9,400 \mathrm{t}(0.04 \mathrm{t} / \mathrm{ha})$, or $3 \%$ of the amount sequestered and avoided. In net, the urban forest removes approximately $304,000 t(1.2 t / h a)$ each year, with an implied value of US $\$ 3.3$ million ( $\$ 0.55 /$ tree). Carbon dioxide reduction by Sacramento's urban forest offsets the total amount of $\mathrm{CO}_{2}$ emitted as a byproduct of human consumption by $1.8 \%$. Most benefits accrue on residential lands in the city and suburban sectors, where rates of storage and sequestration are about one-half those reported for U.S. forests. Guidelines for managing urban forests to reduce atmospheric $\mathrm{CO}_{2}$ are presented.
\end{abstract}

Keywords. Climate change; urban ecosystem, sequestration

Increasing concentrations of greenhouse gases in the atmosphere are linked with the increased risk of global climate change. This risk has prompted electric utilities and other organizations to examine alternative actions to offset emissions associated with power generation. The Climate Challenge, a partnership between the U.S. Department of Energy and electric utilities, is one initiative to voluntarily return greenhouse gases to 1990 levels. Because urban and community forests can reduce atmospheric carbon dioxide $\left(\mathrm{CO}_{2}\right)$-the most important heat-trapping gas-tree planting and stewardship is recognized as one emission reduction strategy. However, adoption of urban forestry as a mitigation measure has been hampered by limited information on how the forests in which we live influence energy and $\mathrm{CO}_{2}$ fluxes. The goal of this study is to increase our understanding of urban forest impacts on atmospheric $\mathrm{CO}_{2}$ levels. Specific objectives are to estimate the amount of $\mathrm{CO}_{2} 1$ ) stored in Sacramento's existing urban forest, and 2) removed from the atmosphere over the course of a year. This study extends previous research on Chicago's urban forest (Nowak 1994) by incorporating $\mathrm{CO}_{2}$ released into the atmosphere through tree care activities and including a more comprehensive accounting of emission reductions due to energy conservation (Simpson
1998). To be consistent with greenhouse gas reporting conventions, all data are reported using the full molecular weight of $\mathrm{CO}_{2}$ (multiply by 0.273 to obtain atomic weight as carbon) and in terms of kilograms (kg) and metric tons (t, or 1,000 kg).

\section{Background}

Urban forests can reduce atmospheric $\mathrm{CO}_{2}$ in two ways. Trees directly sequester $\mathrm{CO}_{2}$ as woody and foliar biomass while they grow. Also, trees around buildings can reduce the demand for heating and air conditioning, thereby reducing emissions associated with electric power production.

Carbon dioxide storage and sequestration. Carbon dioxide storage refers to the accumulation of woody biomass as trees grow over time. The amount of $\mathrm{CO}_{2}$ stored at any one time by urban trees is proportional to their biomass and influenced by the amount of existing tree canopy cover, tree density, and the pattern of tree diameters within a city (McPherson 1994). For example, in heavily treed Shorewood, Wisconsin ( $39 \%$ tree cover), $\mathrm{CO}_{2}$ storage is $119 \mathrm{t}$ per ha (Dorney et al. 1984), while in more sparsely treed Oakland, California ( $21 \%$ tree cover), it is 40 t per ha (Nowak 1993).

Carbon dioxide sequestration refers to the annual rate of storage of $\mathrm{CO}_{2}$ in above- and below-ground biomass over the course of one growing season. Sequestration depends on tree growth and mortality, which in turn depends on species composition and age structure of the urban forest. Relatively little data exist concerning sequestration by urban trees. Radial trunk growth data were used to calculate annual sequestration for major genera in Chicago (Jo and McPherson 1995; Nowak 1994). Sequestration ranged from $16 \mathrm{~kg}$ per year $(35 \mathrm{lb})$ for trees with 8 to $15 \mathrm{~cm}$ ( 3 to $6 \mathrm{in}$.) dbh to $340 \mathrm{~kg}$ per year $(748 \mathrm{lb})$ for trees greater than $76 \mathrm{~cm}$ (30 in) dbh.

Avoided power plant emissions. Tree shade (direct effect) reduces summer air-conditioning demand but can increase heating energy use by intercepting winter irradiance. Lowered air temperatures and wind speeds from increased tree cover (indirect effect) decrease both cooling and heating demand. A computer simulation analysis of 254 residential properties participating in a utility-sponsored tree planting program in Sacramento found than an annual cooling savings 
of US\$15.25 per mature tree was reduced by a heating penalty of $\$ 5.25$ per tree (Simpson and McPherson 1998a). These savings are expected to double as a result of reduced neighborhood air temperature from the projected $7 \%$ increase in tree canopy cover. Windspeed reductions add savings of $\$ 4$ per tree, for an estimated total savings of $\$ 24$ per tree.

Regional variations in climate and the mix of fuels that produce energy to heat and cool buildings influence potential $\mathrm{CO}_{2}$ emission reductions. Emission reductions from urban forestry are likely to be greatest in regions with large numbers of air-conditioned buildings and long cooling seasons. Also, savings can be substantial in areas of the country where coal is the primary fuel for electric power generation. Coal-fired power plants emit 3 to 4 times more $\mathrm{CO}_{2}$ per unit of energy produced than do plants powered by cleaner fuels such as natural gas.

Carbon dioxide release. Little is known about the amount of $\mathrm{CO}_{2}$ released through tree planting and care activities. A study of residential greenspace in Chicago found that about $60 \%$ of the $\mathrm{CO}_{2}$ sequestered each year was released back to the atmosphere through landscape maintenance activities and decomposition (Jo and McPherson 1995). Woody biomass pruned from trees and shrubs each year was taken to a landfill, and the amount of $\mathrm{CO}_{2}$ eventually released through decomposition was equal to $15 \%$ of the $\mathrm{CO}_{2}$ sequestered. Urban trees are usually removed soon after they die and are frequently recycled as landscape mulch or sold as firewood. Burning of tree wood results in nearly complete release of stored $\mathrm{CO}_{2}$, while the rate of release associated with the decomposition of mulch is much slower, depending on local climate and soil conditions (about 2 to $3 \mathrm{~cm}$ [0.8 to $1.2 \mathrm{in}$.] per year in California). Decomposition of urban waste wood that is disposed of in landfills can take decades. Wood salvaged for use in wood products survives 50 years on the average, before becoming landfill and gradually decomposing (Norse 1990). The combustion of gasoline and diesel fuels by vehicle fleets and by such equipment as chainsaws, chippers, stump removers, and leaf blowers is another source of $\mathrm{CO}_{2}$ that has not been fully quantified.

\section{Methods}

Study site and tree measurements. For an explanation of the study site and sampling units, see pages $175-177$ of this issue.

Land use and land cover were interpreted from black and white aerial photographs as the first step of a twostage sampling process (McPherson 1998). Vegetation and other surface data were collected on 675 randomly located $10 \times 10 \mathrm{~m}(33 \times 33 \mathrm{ft})$ plots established as a sample of grid points from the aerial photographs. Information used to calculate carbon storage and sequestration included species, trunk diameter at breast height

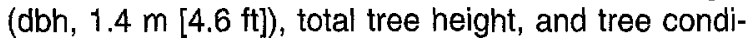
tion. These data were collected for 445 woody plants growing in tree form (i.e., greater than $2 \mathrm{~m}[6.6 \mathrm{ft}]$ tall, open grown, tree-like form).

Carbon storage and sequestration. Carbon stored in tree biomass was estimated using ground survey information of species, diameter, and height, as input for tree biomass equations for 28 tree species (Table 1). If no equation for a particular species existed, the biomass estimate was derived from the formula for a species within the same genus. Equations for general hardwoods, softwoods, and palms were used in cases for which genera-specific formulas were not available.

Published biomass equations used to compute total tree biomass, above-ground biomass only, or wood volume may be on a fresh- or dry-weight basis. Those used to compute above-ground biomass were divided by 0.78 to convert to total tree biomass. Equations used to compute wood volume were divided by 0.75 . These conversion factors are derived from a tree biomass distribution with $3 \%$ of the biomass in foliage and $22 \%$ in the stump/root system (Husch et al. 1982; Tritton and Hornbeck 1982; Wenger 1984). Results of biomass equations used to compute fresh-weight biomass for hardwoods and softwoods were multiplied by 0.56 and 0.48 , respectively, to derive dry-weight biomass based on average moisture content of the species, genus, or group (e.g., Stanek and State 1978; Phillips 1981; Husch et al. 1982). Total dry-weight biomass estimates for each individual tree were converted to total carbon storage estimates by multiplying by 0.50 (Lieth 1963; Whittaker and Likens 1973).

One limitation to the use of biomass formulas derived from forest trees is that they may not accurately reflect biomass for open-grown urban trees. A comparison of measured weight and formula-derived weights for 30 street trees in Oak Park, Illinois, found that, on average, formula-derived estimates were $20 \%$ greater than actual tree weights (Nowak 1994). Based on these results, formula-derived estimates of carbon storage were reduced by $20 \%$ in this study. Carbon storage values were converted to $\mathrm{CO}_{2}$ by multiplying by 3.67 , the molecular weight of carbon dioxide. Total $\mathrm{CO}_{2}$ stored and $\mathrm{CO}_{2}$ stored per hectare is reported for each sector, SubRAD (Sub-Regional Assessment District), and land use using statistical inference from sampled data (McPherson 1998).

To estimate the amount of $\mathrm{CO}_{2}$ sequestered by the current urban forest, trees were "grown" for 1 year and total storage was recalculated. Sequestration 
Table 1. Attributes of biomass equations used to predict carbon dioxide storage $(\mathrm{n} / \mathrm{a}=$ variable not used in equation or data not available).

\begin{tabular}{|c|c|c|c|}
\hline Species & $\begin{array}{l}\text { Dbh } \\
\text { range }(\mathrm{cm})\end{array}$ & $\begin{array}{l}\text { Height } \\
\text { range }(\mathrm{m})\end{array}$ & Reference \\
\hline Palms & $\mathrm{n} / \mathrm{a}$ & $\mathrm{n} / \mathrm{a}$ & Frangi and Lugo 1985 \\
\hline General hardwoods & $>10$ & $\mathrm{n} / \mathrm{a}$ & Harris et al. 1973 \\
\hline General softwoods & $2.5-55$ & $5-30$ & Monteith 1979 \\
\hline Maple & $2.5-66$ & $n / a$ & Young et al. 1980 \\
\hline Birch & $2.5-51$ & $\mathrm{n} / \mathrm{a}$ & Young et al. 1980 \\
\hline Pecan & $5-51$ & $\mathrm{n} / \mathrm{a}$ & Brenneman et al. 1978 \\
\hline Hackberry & $\mathrm{n} / \mathrm{a}$ & $\mathrm{n} / \mathrm{a}$ & Hahn 1984 \\
\hline Camphor & $13-69$ & $5-17$ & Pillsbury and Thompson 1995 \\
\hline Dogwood & $<12.7$ & $\mathrm{n} / \mathrm{a}$ & Phillips 1981 \\
\hline Eucalyptus & $\mathrm{n} / \mathrm{a}$ & $n / a$ & Pillsbury and Thompson 1995 \\
\hline Ash & $5-51$ & $\mathrm{n} / \mathrm{a}$ & Brenneman et al. 1978 \\
\hline Juniper & $n / a$ & $n / a$ & Hahn 1984 \\
\hline Walnut & $\mathrm{n} / \mathrm{a}$ & $n / a$ & Hahn 1984 \\
\hline Sweetgum & $14-54$ & $7-20$ & Pillsbury and Thompson 1995 \\
\hline Spruce & $2.5-66$ & $n / a$ & Young et al. 1980 \\
\hline Pine & $\mathrm{n} / \mathrm{a}$ & $\mathrm{n} / \mathrm{a}$ & Pillsbury and Thompson 1995 \\
\hline London plane & $\mathrm{n} / \mathrm{a}$ & $\mathrm{n} / \mathrm{a}$ & Hahn 1984 \\
\hline Poplar & $5-84$ & $\mathrm{n} / \mathrm{a}$ & Ker 1980 \\
\hline Aspen & $6-35$ & $5-26$ & Standish et al. 1985 \\
\hline Cottonwood & $6-32$ & $7-25$ & Standish et al. 1985 \\
\hline Cherry & $5-51$ & $\mathrm{n} / \mathrm{a}$ & Brenneman et al. 1978 \\
\hline Blue oak & $10-70$ & $\mathrm{n} / \mathrm{a}$ & Pillsbury and Kirkiey 1984 \\
\hline Holly oak & $13-52$ & $\mathrm{n} / \mathrm{a}$ & Pillsbury and Thompson 1995 \\
\hline California black oak & $10-110$ & $\mathrm{n} / \mathrm{a}$ & Pillsbury and Kirkley 1984 \\
\hline Valley oak & $10-100$ & $\mathrm{n} / \mathrm{a}$ & Pillsbury and Kirkley 1984 \\
\hline Interior live oak & $10-70$ & $\mathrm{n} / \mathrm{a}$ & Pillsbury and Kirkley 1984 \\
\hline Giant redwood & $97-614$ & $\mathrm{n} / \mathrm{a}$ & Means et al.1994 \\
\hline Elm & $17-56$ & $n / a$ & Pillsbury and Thompson 1995 \\
\hline
\end{tabular}

ther information on statistical procedures). These standard errors report sampling error, not error of estimation. The reported sampling errors underestimate the actual standard errors. Lack of information regarding errors in the biomass equations and adjustment factors make it impossible to fully account for estimation error associated with these projections.

Avoided power plant emissions. Estimates of air-conditioning and spaceheating energy savings from the existing urban forest served as a basis for estimating $\mathrm{CO}_{2}$ emission reductions (Simpson 1998). Carbon dioxide emission factors for electricity ( $400 \mathrm{t} / \mathrm{GWh}$ ) and natural gas (63 t/TJ [terajoule]) were obtained from local utilities (Beebe, personal communication 3/8/ 96) to convert energy savings estimates to $\mathrm{CO}_{2}$ emission reductions.

Carbon dioxide release. To estimate annual $\mathrm{CO}_{2}$ release through contracted tree care activities it was necessary to identify the number, location, and sizes of trees that receive professional care and the rate of emissions per tree visited. Survey data indicate

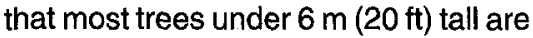
maintained by residents themselves was calculated as the difference between $\mathrm{CO}_{2}$ stored in successive years. Annual tree height and diameter growth were calculated for trees in different size classes based on limited measurements of Sacramento street and yard trees with known planting dates (Table 2) (Simpson and McPherson 1995; Small 1997). To account for the fact that dead trees (condition = $0 \%$ ) should not grow at all and healthy trees (condition $=90 \%$ ) should grow more than trees in poor condition (condition $=20 \%$ ), the appropriate annual height and diameter increments selected for each tree in the current year were multiplied by each tree's surveyed condition. These adjusted height and diameter growth increments were added to the current tree height and diameter to estimate dimensions for the next year. It is assumed that there are no changes in tree condition or numbers (no mortality or tree planting) during the hypothetical growing season.

Standard errors (se) are reported for estimates of $\mathrm{CO}_{2}$ storage and sequestration (see Appendices $\mathrm{A}$ and $B$ in McPherson 1998 [page 189 of this issue] for fur-
(Summit and McPherson 1998). As tree height increased, the percentage of trees receiving professional care increased. Typically, large trees are contractually pruned about once every 5 years.

For this study, it is assumed that trees less than 16 $\mathrm{cm}$ (6 in.) dbh are pruned, sprayed, and removed by residents and no $\mathrm{CO}_{2}$ is released. Also, trees in agricultural and vacant/wild land uses receive little if any care, and thus no $\mathrm{CO}_{2}$ is released. The remaining trees

Table 2. Annual tree growth increments for different tree size classes used to model carbon dioxide sequestration (units in parentheses are feet and inches).

\begin{tabular}{llll}
\hline $\begin{array}{l}\text { Height } \\
\text { class }(\mathrm{m})\end{array}$ & $\begin{array}{l}\text { Height } \\
\text { growth } \\
(\mathrm{m} / \mathrm{yr})\end{array}$ & $\begin{array}{l}\text { Dbh } \\
\text { class }(\mathrm{cm})\end{array}$ & $\begin{array}{l}\text { Dbh } \\
\text { growth } \\
(\mathrm{cm} / \mathrm{yr})\end{array}$ \\
\hline $2-7.9(6.6-25.9)$ & $0.5(1.6)$ & $1-24.9(0.4-9.8)$ & $1.8(0.7)$ \\
$8-12.4(26-40.7)$ & $0.4(1.3)$ & $25-44.9(9.9-17.7)$ & $1.5(0.6)$ \\
$12.5-14.9(40.8-48.9)$ & $0.3(1.0)$ & $45-59.9(17.8-23.6)$ & $1.0(0.4)$ \\
$15-18.4(49-60.4)$ & $0.2(0.7)$ & $60+(23.7+)$ & $0.3(0.1)$ \\
$18.5+(60.5+)$ & $0.1(0.3)$ & & \\
\hline
\end{tabular}


are assumed to be professionally visited on a 5-year cycle and appropriate release rates are applied to trees in each dbh class.

To estimate $\mathrm{CO}_{2}$ release per tree serviced, information was obtained from the Sacramento Tree Services Division on the amount of gasoline, diesel, and oil consumed annually and the number of trees pruned, removed, inspected, and treated with pesticides. Fuel use was converted to $\mathrm{CO}_{2}$ and the average release rate per tree was calculated as $\mathrm{kg}$ per $\mathrm{cm} \mathrm{dbh}$.

Implied costs and per capita emissions. The value to society of reducing atmospheric $\mathrm{CO}_{2}$ (e.g., sea level rise, flooding, habitat loss) is reflected in the implied cost values assigned by state energy commissions. Electric utilities are required to use these values when evaluating the environmental costs associated with different power sources. This study assumes a value of US $\$ 11$ per $\mathrm{CCO}_{2}$ (California Energy Commission 1992).

Because $\mathrm{CO}_{2}$ is an unregulated pollutant, only a few communities have inventoried emissions. Portland, Oregon (Swift and Liebe 1995), and Austin, Texas (City of Austin 1997), estimated annual per capita $\mathrm{CO}_{2}$ emissions at 23 and $15 \mathrm{t}$ per capita, respectively. Because emission data are lacking for Sacramento and the climate and development pattern of Sacramento more closely resemble Austin than Portland, Sacramento emissions are assumed to be $15 \mathrm{t}$ per capita. This value is used to determine the percentage of annual emissions offset by Sacramento's urban forest.

\section{Results And Discussion}

Carbon storage and sequestration. Approximately 8 million $\mathrm{t}$ ( $\mathrm{se}=2.2$ million $\mathrm{t}$ ) of $\mathrm{CO}_{2}(31 \mathrm{t} / \mathrm{ha}$ ) have accumulated and are presently stored in Sacramento County's 6 million trees (Table 3). The city sector's 1.7 million trees store $50 \%$ of the total amount stored, or 172 t per ha. Storage per unit land area in the suburban sector is $41 \mathrm{t}$ per ha. In comparison, trees in the cities of Chicago and Oakland store 52 and 40 t per ha on average, respectively (Nowak 1993, 1994). Forest systems in the United States store $202 \mathrm{t}$ per ha (Birdsey 1992); urban forests in the United States are reported to store about $100 \mathrm{t}$ per ha (Rowntree and Nowak 1991).

Differences in the diameter distribution of tree populations influences $\mathrm{CO}_{2}$ storage. Most natural forests and some urban forests (e.g., Oakland, California) have relatively large numbers of small-sized trees, while the city of Sacramento has a higher percentage of large-diameter trees ( $10 \%$ with $\mathrm{dbh}$ of $\geq 77 \mathrm{~cm}[30$ in.]). For example, the average amount of $\mathrm{CO}_{2}$ stored per tree in the city of Sacramento is $2,343 \mathrm{~kg}(5,165$ $\mathrm{lb})$, compared to $336 \mathrm{~kg}(741 \mathrm{lb})$ in Oakland and 759 $\mathrm{kg}(1,674 \mathrm{lb})$ in the city of Chicago.

A second factor influencing $\mathrm{CO}_{2}$ storage is tree density. Tree density in the rural sector of Sacramento is 10 trees per ha (McPherson 1998) and $\mathrm{CO}_{2}$ storage is only $13 \mathrm{t}$ per ha (Table 3 ). Although on average trees are larger in the rural sector than in the suburban sector, the lower tree density yields a lower storage rate. Natural forests (100s to 1,000s trees/ha) and urban forests with large wildland tree cover, such as Oakland (120/ha), tend to have higher tree densities than urban forests. In general, data from Sacramento, Chicago, and other cities indicate that urban forests have fewer, but on average, larger-sized trees per ha compared to natural forests. Although there is great variation in the amount of $\mathrm{CO}_{2}$ stored by different natural forest types, overall, urban forests typically store about one-half as much $\mathrm{CO}_{2}$ as natural forests.

Carbon dioxide storage by Sacramento's urban forest varies geographically, reflecting spatial differences in tree size and density (Figure 1). On a per-hectare basis, relatively low rates of storage occur in the rural sector, as well as in the Sacramento core commercial area (see the inset in Figure 1). Older, residential areas surrounding the old city center (Figure 1 inset) have the highest storage rates (100 to $167 \mathrm{t} / \mathrm{ha}$ ). Storage rates range from 20 to $100 \mathrm{t}$ per ha in the more recently developed suburban areas extending south and northeast from the city center. One corridor runs south following the Sacramento River and interstate 5. A second corridor extends northeast through progressively more recent suburban development to the Folsom area (Figure 1). 


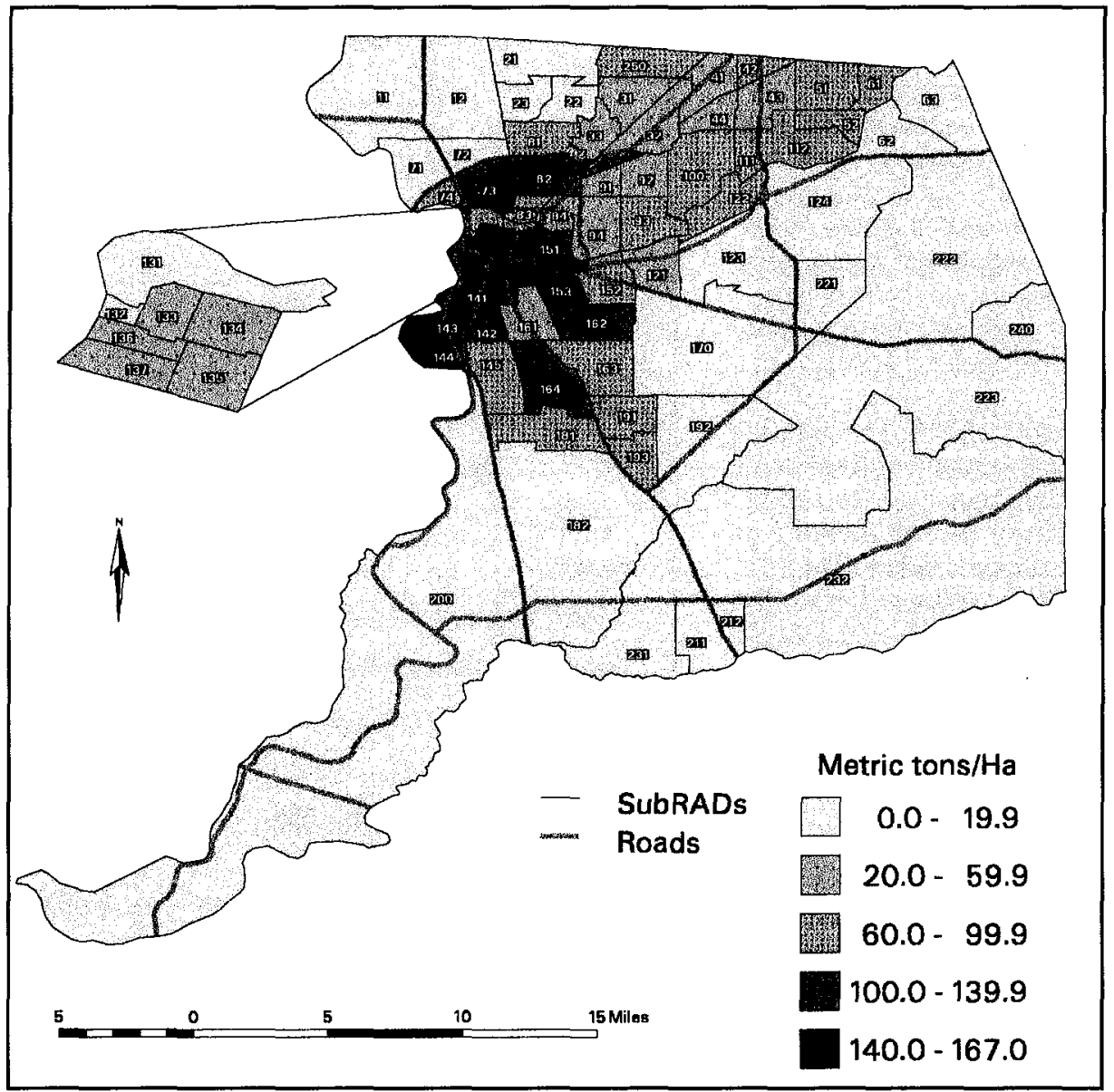

Figure 1. Carbon dioxide stored in tree biomass per unit land area is greatest in older areas surrounding the city center (inset) and diminishes in areas of recent suburban growth to the northeast and south.

Sacramento County's 6 million trees are estimated to sequester about $238,000 \mathrm{t}(0.92 \mathrm{t} / \mathrm{ha})$ of $\mathrm{CO}_{2}$ over the course of a year (Table 3 ). While $\mathrm{CO}_{2}$ is principally stored in the city sector, where the "big" trees are most plentiful, sequestration is greatest in the suburban sector $(40 \%$ of total), where the largest number of trees are found (2.4 million). Carbon dioxide sequestration rates are similar for the city ( $3.1 \mathrm{t} / \mathrm{ha})$ and suburban (2.6 t/ha) sectors, but substantially less for the rural sector $(0.4 \mathrm{t} / \mathrm{ha})$ due to lower tree density. This pattern is evident in Chicago as well. However, unlike Sacramento, tree density and sequestration in Chicago increase along the urban-to-rural gradient, rising from $2.4 \mathrm{t}$ per ha in the city (69 trees/ha) to $3.8 \mathrm{t}$ per ha in the rural sector (171 trees/ha) (Nowak 1994). Trees in natural forests sequester about twice as much $\mathrm{CO}_{2}$ as urban forests per unit land area, between 4 and $8 \mathrm{t}$ per ha on average (Birdsey 1992). However, because urban trees tend to grow faster than rural trees, they sequester more $\mathrm{CO}_{2}$ on a per tree basis (Jo and McPherson 1995). Average annual sequestration rates ranged from 35 to 43 and 22 to $36 \mathrm{~kg}$ per tree for the three sectors in Sacramento and Chicago, respectively.

Avoided power plant emissions. Building shade, summer cooling, and windspeed reductions attributed to the region's urban forest reduce electricity consumed annually for air conditioning by $11 \%$ (157 GWh) and natural gas heating use by $0.7 \%$ (145 TJ) (Simpson 1998). By conserving this amount of energy over the course of a year, approximately $75,600 \mathrm{t}(0.29 \mathrm{t} / \mathrm{ha})$ of $\mathrm{CO}_{2}$ emissions are avoided (Table 3). Airconditioning savings provide $83 \%(63,000 t)$ of the total $\mathrm{CO}_{2}$ emission reductions from trees in Sacramento County. Trees in the rural sector produce only $11 \%$ of the county-wide total because relatively few trees are near buildings. The remaining $\mathrm{CO}_{2}$ emission reductions are nearly evenly distributed between the city and suburban sectors. Trees in these largely urbanized sectors are responsible for average annual emission reductions of 1.4 and 0.93 t per ha, respectively (Table 3 ). On an average annual per tree basis, avoided $\mathrm{CO}_{2}$ emissions are 19,15 , and $4 \mathrm{~kg}$ for the city, suburban, and rural sectors.

Avoided emissions are about one-third of the amount of $\mathrm{CO}_{2}$ sequestered in trees. This finding differs from other studies that projected much higher $\mathrm{CO}_{2}$ avoided:sequestered ratios of $15: 1$ and $4: 1$ for national urban tree planting programs (Akbari et al. 1989; Nowak 1993). However, a very low ratio of $1: 28$ was reported for Chicago (Nowak 1994). The relatively low 
ratios for Sacramento and Chicago are due in part to local supplies of clean, hydroelectric and nucleargenerated electricity. Applying the average national power plant emission factor $(1,300 \mathrm{~kg} / \mathrm{MWh}$, Akbari et al. 1989) in Sacramento results in a nearly $1: 1$ ratio, as avoided emissions would increase to $222,000 \mathrm{t}$. Also, the low ratios for urban forests in Sacramento and Chicago reflect the difference between energy savings from the frequently haphazard locations of existing trees and larger savings projected for programs designed to strategically locate trees for energy conservation purposes.

Carbon dioxide release. In 1996, the Sacramento Tree Services Division's vehicle fleet and fossil-fuel powered equipment released $1,720 \mathrm{~kg}$ of $\mathrm{CO}_{2}$ while visiting approximately 55,750 street and park trees (Fitch, personal communication 6/10/97). Assuming an average $\mathrm{dbh}$ of $61 \mathrm{~cm}(24 \mathrm{in}$.$) , the \mathrm{CO}_{2}$ emission rate is $0.51 \mathrm{~kg}$ per $\mathrm{cm}$ dbh. Given the location and diameter distribution of the county's 6 million existing trees, approximately $9,422 \mathrm{t}$ of $\mathrm{CO}_{2}$ are released annually in their maintenance (Table 3 ). This amount is $3 \%$ of total $\mathrm{CO}_{2}$ sequestered and avoided annually by Sacramento's urban forest.

Eighty percent of total annual $\mathrm{CO}_{2}$ released by tree maintenance occurs in the city and suburban sectors, with the remaining $20 \%$ in the rural sector. In the city and suburban sectors the release rates are 0.17 and $0.10 \mathrm{t}$ per ha and 2.3 and $1.6 \mathrm{~kg}$ per tree, respectively. Values are much lower for rural sector trees because $24 \%$ of these trees are located in vacant/wild lands where no maintenance is assumed.

Net carbon dioxide conservation. Net atmospheric $\mathrm{CO}_{2}$ reduction by Sacramento's urban forest is approximately $304,000 \mathrm{t}(1.2 \mathrm{t} / \mathrm{ha})$ of atmospheric $\mathrm{CO}_{2}$ over the course of a year (Table 3 ). The implied value of this annual benefit is about US $\$ 3.3$ million dollars, or $\$ 0.55$ per tree on average. Net benefits are greatest in the suburban sector (\$1.4 million), where the largest number of trees are located. However, on a land area basis, the implied value of benefits are greatest in the city sector $(\$ 48 /$ ha, $\$ 0.65 /$ tree).

The distribution of $\mathrm{CO}_{2}$ removal and release varies widely by land use, as well as by sector (Figure 2). Countywide, $61 \%$ of net $\mathrm{CO}_{2}$ removal occurs in residential land uses, $20 \%$ in vacant/wild lands, and $13 \%$ in institutional lands. However, in the more urbanized city and suburban sectors, $75 \%$ of all removal takes place in residential land uses. This result coincides with the finding that within these 2 sectors, where $90 \%$ of all residents live, about $75 \%$ of total tree numbers, basal area, and leaf area occur on residential land (McPherson 1998). Relatively more $\mathrm{CO}_{2}$ is removed in multifamily residential and institutional lands within the

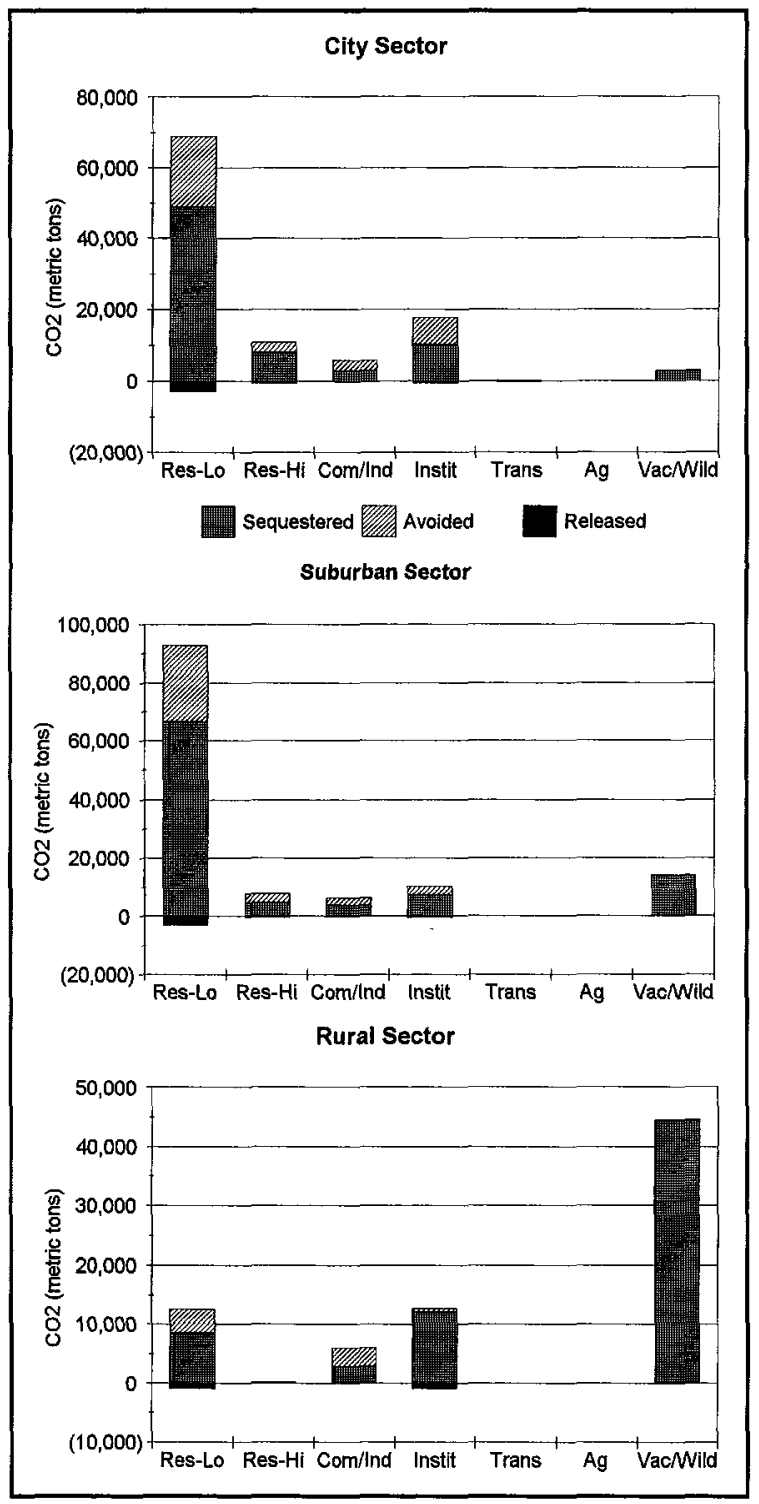

Figure 2. Annual $\mathrm{CO}_{2}$ removal and release occurs primarily in low-density residential areas (1 to 3 units per structure) within the city and suburban sectors, and in vacant/wild lands in the rural sector.

city sector than in the suburban sector. However, trees in vacant/wild lands within the suburban sector remove substantially more $\mathrm{CO}_{2}$ than do the relatively small number of vacant/wild trees in the city (Figure 2). Trees in vacant/wild land uses account for $60 \%$ of all $\mathrm{CO}_{2}$ removal in the rural sector.

Carbon dioxide emitted as a byproduct of Sacramento County residents' consumption (e.g., transportation, electricity and natural gas use, other 
gas-powered machines) is estimated to be 17 million t (17 Mt) per year. The net impact of Sacramento's urban forest on $\mathrm{CO}_{2}$ removal is to offset these emissions by approximately $1.8 \%$. The $8 \mathrm{Mt}$ of $\mathrm{CO}_{2}$ stored in Sacramento's trees, which has taken many years to accumulate, is equivalent to nearly $50 \%$ of the region's total annual emissions. This storage rate is relatively greater than reported for Chicago, where stored $\mathrm{CO}_{2}$ in tree biomass equaled the amount released from the residential sector during a 5-month period (including transportation use) (Nowak 1994). This difference reflects regional variations in lifestyle, commuting patterns, climate, and building energy use; as well as different urban forest composition and structure.

Managing urban forests for $\mathrm{CO}_{2}$ reductions. Ultimately, all the $\mathrm{CO}_{2}$ presently stored in Sacramento's trees will be lost upon their death and removal. By maintaining the health of mature trees, the rate at which $\mathrm{CO}_{2}$ is lost via tree removal and decomposition can be forestalled. By planting new trees, increasing amounts of $\mathrm{CO}_{2}$ can be stored until an equilibrium is reached, with sequestration by replacement plantings offsetting decomposition from dead trees. The Sacramento Municipal Utility District (SMUD) and Sacramento Tree Foundation (STF) have pledged to plant 500,000 shade trees to achieve $200,000 \mathrm{t}$ of $\mathrm{CO}_{2}$ reductions per year by the year $2000(155,000 \mathrm{t}$ from sequestration and 50,000 $t$ from energy savings) (Moy 1995). Net $\mathrm{CO}_{2}$ stored as a result of planting 188,000 trees from 1991 to 1995 is estimated to be $350,000 \mathrm{t}$ in the year 2030 , with $60 \%$ of net benefits from sequestration (Simpson and McPherson 1998b). This reduction is equivalent to $4 \%$ of the $8 \mathrm{Mt}$ of $\mathrm{CO}_{2}$ currently stored in the region's urban forest.

Because trees provide the potential for longer-term storage compared to nonwoody vegetation, net $\mathrm{CO}_{2}$ storage can be increased more effectively through judicious tree management than by altering other landscape components (i.e., soils, grasses, herbaceous plants). Additionally, tree maintenance appears to have a relatively minor impact on net $\mathrm{CO}_{2}$ reductions. Selecting trees that are well suited to local growing conditions, proper planting and establishment, and regular maintenance to promote vigorous growth and reduce mortality are likely to have more profound impacts on long-term $\mathrm{CO}_{2}$ reductions than attempts to reduce $\mathrm{CO}_{2}$ release associated with tree care.

These findings suggest that trees in residential lands are the principal site of $\mathrm{CO}_{2}$ storage and sequestration. Although residential landscapes are seldom designed and managed to maximize their ability to serve as $\mathrm{CO}_{2}$ sinks, several design and management guidelines can be applied to increase $\mathrm{CO}_{2}$ reductions:
- Maximize use of woody plants, especially trees, because they store more $\mathrm{CO}_{2}$ than do herbaceous plants and grass (Jo and McPherson 1995).

- Increase tree-stocking levels where feasible and immediately replace dead trees to compensate for $\mathrm{CO}_{2}$ lost through tree and stump removal.

- Create a diverse assemblage of habitats, with trees of different ages and species, to promote a continuous canopy cover over time.

- Select species that are adapted to local climate, soils, and other growing conditions. Adapted plants should thrive in the long run and consume relatively little $\mathrm{CO}_{2}$ through maintenance.

- Group species with similar landscape maintenance requirements together and consider how irrigation, pruning, fertilization, weed, pest, and disease control can be minimized.

- Reduce $\mathrm{CO}_{2}$ associated with landscape management by using push mowers (not gas or electric), handsaws (not chainsaws), pruners (not gas or electric shears), rakes (not leaf blowers), and employ landscape professionals who don't have to travel far to your site.

- Consider the project's lifespan when making species selection. Fast-growing species will sequester more $\mathrm{CO}_{2}$ initially than slow-growing species, but may not live as long.

- Provide a generous below-ground environment for the trees in order to maximize initial $\mathrm{CO}_{2}$ sequestration and longevity.

- When trees die or are removed, salvage as much wood as possible for use as furniture and other long-lasting products to forestall decomposition (Sherrill et al. 1997).

- Plant trees, shrubs, and vines in strategic locations to maximize summer shade and reduce winter shade, thereby reducing atmospheric $\mathrm{CO}_{2}$ emissions associated with power production.

Although not a panacea for reducing the risks of global climate change, Sacramento's urban forest plays an important role through offsetting regional $\mathrm{CO}_{2}$ emissions by nearly $2 \%$ annually. SMUD and STF's shade tree program demonstrates the potential for urban forestry to be one of many measures employed by electric utilities to offset their $\mathrm{CO}_{2}$ emissions. The tree program is projected to achieve $3 \%$ of SMUD's total emission reduction target. In this new era of utility deregulation and environmental protection, an increasing number of electric utilities are likely to follow SMUD's example. Electric utilities, local communities, 
and residential customers stand to benefit from costeffective shade tree programs that attract new customers, improve quality of life, conserve energy, and offset $\mathrm{CO}_{2}$ emissions.

Acknowledgments. This study would not have been possible without field data collected by the following individuals: Vance Howard, Richard Bagaoisan, Melissa Kaufman, TinWah Wong, Nina Luttinger, Uma Ramakrishnan, Katherine McGuinn, Linda Roberson, and Ali Griffith. Ellen Zygory and Warren Roberts (both at the UC-Davis Arboretum) provided invaluable assistance with plant identification. Sylvia Mori (U.S. Forest Service) provided helpful statistical consultation. Klaus Scott, Andrew Hertz (U.S. Forest Service), and Qingfu Xaio (UC-Davis) managed the database and produced maps. Drs. Alison Berry, Jim Harding, and Dave Burger (UCDavis Department of Environmental Horticulture) provided additional assistance throughout the course of the study. Acquisition of aerial photography, demographic, and geographic information was made possible by Craig Crouch and Rick Stassi (County of Sacramento), Dennis Ybarra (City of Sacramento), and Robert Faseler and Ken Gebert (Sacramento Area Council of Governments). I received valuable comments on earlier versions of this manuscript from Dr. Jim Simpson (U.S. Forest Service) and Peggy Sand (Minnesota DNR).

\section{Literature Cited}

Akbari, H., J. Huang, P. Martien, L. Rainer, A. Rosenfeld, and $H$. Taha. 1989. Saving energy and reducing atmospheric pollution by controling summer islands. $\mathrm{pp}$ 31-44. In Garbesi, K., H. Akbari, and P. Martien (Eds.). Controlling Summer Heat Islands. Lawrence Berkeley Laboratory, Berkeley, CA.

Birdsey, R. 1992. Carbon Storage and Accumulation in United States Forest Ecosystems. USDA For. Serv. Northeast. For. Exp. Sta., Radnor, PA.

Brenneman, B.B., D.J. Fredrick, W.E. Gardner, L.H. Schoenhofen, and P.L. Marsh. 1978. Biomass of species and stands of West Virginia hardwoods. Proceedings Central Hardwood Forest Conference II. pp 59-178.

California Energy Commission. 1992. 1992 Electricity Report: Appendix F. California Energy Commission, Sacramento, CA.

City of Austin. 1997. City of Austin Carbon Dioxide Reduction Strategy. City of Austin, Austin. TX.

Dorney, J.R., G.R. Guntenspergen, J.R. Keough, and F. Stearns. 1984. Composition and structure of an urban woody plant community. Urb. Ecol. 8:69-90.

Frangi, J.L., and A.E. Lugo. 1985. Ecosystem dynamics of a subtropical floodplain forest. Ecol. Monogr. 55:351-369.

Hahn, J.T. 1984. Tree Volume and Biomass Equations for the Lake States. USDA For. Serv., St. Paul, MN.

Harris, W.F., R.A. Goldstein, and G.S. Henderson. 1973. Analysis of forest biomass pools, annual primary production and turnover of biomass for a mixed deciduous forest watershed. IUFRO Biomass Studies, 41-64.

Husch, B., C.I. Miller, and T.W. Beers. 1982. Forest Mensuration. John Wiley and Sons, New York, NY.
Jo, H.K., and E.G. McPherson. 1995. Carbon storage and flux in urban residential greenspace. J. Environ. Manag. 45:109-133.

Ker, M.F. 1980. Tree Biomass Equations For Ten Major Species in Cumberland County, Nova Scotia. Canadian For. Serv., Maritimes For. Res. Centre. Inf. Rep. M-X$108,26$.

Lieth, $H .1963$. The role of vegetation in the carbon dioxide content of the atmosphere. J. Geophys. Res. 68:38873898.

McPherson, E.G. 1994. Using urban forests for energy efficiency and carbon storage. J. For. 92:36-41.

McPherson, E.G. 1998. Structure and sustainability of Sacramento's urban forest. J. Arboric. 24(4):174-190.

Means, J.E., H.A. Hansen, G.J. Koerper, P.B. Alaback, and M.W. Klopsch. 1994. Software for Computing Plant Biomass-BIOPAK Users Guide. USDA For. Serv. Pac. Northwest Res. Sta.

Monteith, D.B. 1979. Whole-Tree Weight Tables For New York. AFRI Res. Rep. 40:67.

Moy, K. 1995. SMUD to sign contract to cut global warming. Sacramento Bee. Jan. 17.

Norse, E. 1990. Ancient Forests of the Northwest. The Wilderness Society and Island Press, Washington, DC.

Nowak, D. 1993. Atmospheric carbon reduction by urban trees. J. Environ. Manag. 37:207-217.

Nowak, D.J. 1994. Atmospheric carbon dioxide reduction by Chicago's urban forest, pp 83-94. In McPherson, E.G., D.J. Nowak, and R.A. Rowntree (Eds.). Chicago's Urban Forest Ecosystem: Results of the Chicago Urban Forest Climate Project. USDA For. Serv. Northeast. For. Exp. Sta., Radnor, PA.

Phillips, D.R. 1981. Predicted Total-Tree Biomass of Understory Hardwoods. USDA For. Serv., Asheville, NC.

Pillsbury, N.H., and M.L. Kirkley. 1984. Equations for Total, Wood, and Saw-Log Volume for Thirteen California Hardwoods. USDA For. Serv., Portland, OR.

Pillsbury, N., and R. Thompson. 1995. Tree Volume Equations For Fifteen Urban Species in California. Urban Forest Ecosystems Institute. Calif. Polytech. St. Univer., San Luis Obispo, CA.

Rowntree, R.A., and D.J. Nowak. 1994. Quantifying the role of urban forests in removing atmospheric carbon dioxide. J. Arboric. 17:269-275.

Sacramento Area Council of Governments. 1995. Population estimates for the Sacramento-Yolo CMSA. In 1995 Data Summary. Sacramento, CA.

Sherrill, S., C. Sherrill, and M. Romanos. 1997. The nuts and bolts of turning waste trees into good wood. Pop. Woodworking. 17:30-33.

Simpson, J.R. 1998. Urban forest impacts on regional cooling and heating energy use: Sacramento County case study. J. Arboric. 24(4):201-214.

Simpson, J.R., and E.G. McPherson. 1995. Impact Evaluation of the Sacramento Municipal Utility District's Shade Tree Program. USDA For, Serv. West, Ctr. for Urban For. Res. and Educ., Davis, CA.

Simpson, J.R., and E.G. McPherson. 1998a. Simulation of tree shade impacts on residential energy use for space conditioning in Sacramento. Atmos. Environ.: Urban Atmos. 32:69-74. 
Simpson, J.R., and E.G. McPherson. 1998b. A tool for evaluating carbon reduction by urban forestry programs, pp 58-61. In Kollin, S. (Ed.). Proceedings of the Eighth National Urban Forest Conference. American Forests, Washington DC.

Small, B.M. 1997. Tree Growth under Sacramento Shade. Sacramento Tree Foundation, Sacramento, CA.

Standish, J.T., G.H. Manning, and J.P. Demaerschalk. 1985. Development of Biomass Equations for British Columbia Tree Species. Inf. rep. BC-X-264. Can. For. Serv. Pac. For. Ctr., Vancouver, BC.

Stanek, W., and D. State. 1978. Equations Predicting Primary Productivity (Biomass) of Trees, Shrubs and Lesser Vegetation Based on Current Literature. Can. For. Serv., Victoria, BC.

Summit, J., and E.G. McPherson. 1998. Residential tree planting and care: $A$ study of attitudes and behaviors in Sacramento, California. J. Arboric. 24(3):89-97.

Swift, J., and L. Liebe. 1995. Portland Today: Urban Environment Update. City of Portland, Portland, OR.

Tritton, L.M., and J.W. Hornbeck. 1982. Biomass Equations for Major Tree Species of the Northeast. USDA For. Serv., Broomall, PA.

Wenger, K.F. 1984. Forestry Handbook. John Wiley and Sons, New York, NY.

Whittaker, R.H., and G.E. Likens. 1973. Carbon in the biota, pp 281-302. In Woodell, G.M., and E.V. Pecans (Eds.). Proceedings of the 24th Brookhaven Symposium in Biology, May 16-18, 1972. Upton, NY. US Atomic Energy Commission. Technical info. Services. Office of Information Services.

Young, H.E., J.H. Ribe, and K. Wainwright. 1980. Weight Tables For Tree and Shrub Species in Maine. Life Sci. and Agric. Exp. Stn. Misc. Rep. 230:84.
Pacific Southwest Research Station

USDA Forest Service

c/o Department of Environmental Horticulture

University of California

Davis, CA 95616

Resumen. Los 6 millones de árboles del Condado de Sacramento (California) almacenan 8 millones de toneladas de bióxido de carbono ( $31 \mathrm{t} / \mathrm{ha}$ ), y retiran anualmente 238,000 toneladas (0.92 tha). Los ahorros de aire acondicionado (157 GWh) y espacio de calentamiento (145 TJ) del bosque urbano reducen además la emisión de 75,600 toneladas de bióxido de carbón anualmente (0.29 t/ha). Estas emisiones evitadas son solamente $32 \%$ de la cantidad retirada, debido a un suministro limpio de energía hidroeléctrica. La liberación anual de bióxido de carbono, asociada con el mantenimiento del árbol, es estimada en 9,400 toneladas (0.04 t/ha), o 3\% de la cantidad retirada y evitada. En términos netos, el bosque urbano remueve aproximadamente 304,000 toneladas (1.2 tha) cada año, con un valor implicado de US $\$ 3.3$ millones ( $\$ 0.55$ por árbol). La reducción del bióxido de carbono por el bosque urbano de Sacramento compensa la cantidad total de bióxido de carbono, emitido como un producto secundario del consumo humano, en $1.8 \%$. Los mayores beneficios se acumulan en áreas residenciales en la ciudad y sectores suburbanos, donde las tasa de almacenaje y retiro son cerca de la mitad de los reportados para los bosques de los Estados Unidos. Se presentan normas para el manejo de los bosques urbanos con el fin de reducir el bióxido de carbono atmosférico. 